\title{
Effect Of System Quality and Information Quality on Crisis Management - An Empirical Study on Jordanian Mobile Telecommunications Companies.
}

\author{
ZAID AHMAD ALABADDI ${ }^{a^{*}}$, ARWA HISHAM RAHAHLEH ${ }^{\mathrm{b}}$, \\ MONIRA ABDALLAH MUFLIH ${ }^{\mathrm{c}}$, JIHAD MOUSA FARAJAT ${ }^{\mathrm{b}}$, \\ SANA'A NAWAF AL-NSOUR ${ }^{\mathrm{c}}$,MOHAMMAD ADNAN ALMAHAMEED ${ }^{\mathrm{a}}$, \\ ${ }^{a}$ Department Of Management Information System,Al-Hussein Bin Talal University,Jordan \\ b Department Of Business Administration ,Al-Hussein Bin Talal University, Jordan \\ ${ }^{c}$ Department Of Business, World Islamic Sciences And Education University, Jordan \\ *Correspondence Author: ${ }^{\text {a* zaid.abaddi@yahoo.com }}$
}

\begin{abstract}
:
This study attempts to identify the impact of system quality and information quality on crisis management in Jordanian mobile telecommunication companies. A survey method was applied through a questionnaire. Zain, Orange and Umniah are Jordanian mobile telecommunications companies that are working in the Hashemite Kingdom of Jordan. A sample of 80 managers participated in this study. The data was analyzed by a descriptive statistics method using the statistical package of social sciences (SPSS).

The results showed a strong statistical significant effect of system quality and information quality on crisis management in the targeted telecommunication companies.

The study concluded that $85.3 \%$ of the variation in crisis management are explained by both (system quality \& information quality) This is an high percentage which illustrates the importance of (system quality \& information quality) and their impact on crisis management. The study recommends paying more attention and focus on studying the different factors of quality measurement in information systems and their impact on crisis
\end{abstract} management.

Keyword: System Quality, Information Quality, Crisis management

DOI: $10.7176 / \mathrm{EJBM} / 12-1-07$

Publication date: January $31^{\text {st }} 2020$

\section{Introduction:}

Information systems help organizations in their operations and support the process of good decision making when organizations face crises in a turbulent business environment. In order to provide information services in light of the rapid changes in the role of information systems, organizations need to provide high-quality information systems that provide services and information required by the users.

It is clear that information remains the main support system in the decision-making process for various organizations. Development in the field of information systems include: methods of information transfer and circulation, the enormous possibilities of computers in their various forms and the emergence of new applications helps support the best decision-making process in a timely manner when dealing with crises.

On the other hand, information systems are used to confront the tremendous amounts of changes in the work environment. In light of the crisis facing such organizations, there is a significant need for information systems in organizations. Moreover, information systems allow organizations to face threats to their survival wisely.

The quality of the information systems and the successful applications have been confirmed by several models including the "Delone and Mclean success model of Information Systems" (DeLone, McLean,1992). The success factors of information systems in the work environments were identified by this model, namely: (system quality $\&$ information quality). This model has been used in several researches that examined the impact of information systems quality on the organization's ability to achieve a competitive advantage and better performance.

Furthermore, organizations face many problems related to the poor quality of information which is provided by information systems. In other cases, the quality of information systems in many cases is not efficient enough to clarify and meet the basic need of information. This is especially true in the various stages of crisis management where the organization is in a bad need for accurate information to take decisions. 
This study aims at examining the impact of system quality and information quality on crisis management in the Jordanian mobile telecommunication companies by surveying 80 managers from these companies.

The importance of this study first stems from the urgent need for improving the quality of information systems to uses it in crisis. In addition, it stems from the need to study the implications of the use of information systems, especially in the stages of crisis management. There is also a need for the quality of the information systems to be reflected in the performance of the organization in the stages of crisis management and the survival of the organization during crises.

\section{Literature Review:}

Mittroff's classification of stages of crisis management concluded that: for the organization in order to prepare and confront crises effectively, it is necessary to test the organization's capabilities and development in technical and technological systems. (Pearson and Mittroff, 1993).Similarly, there is an impact of the success of information systems on the performance of individuals and the organization itself (Amin, 2010), (malek \&et al,2018). The effectiveness of management if information system varies at each stage of crisis management and how these companies experience these crises (Khashali and Qutub, 2006). This is confirmed by the (Kamolvej, 2006) who emphasized on the need for a high level of technology and infrastructure in crisis situations. The effective use of information and information systems helps organizations coordinate their actions effectively in crisis situations. There is also a great need for the availability of information and communications systems that allow exchanging information and in taking the correct decisions. The lack of information is one of the most important difficulties facing the action plan in response to crises and that an effective system requires two important elements. First: the development of a single network to respond to crises consisting of the modern infrastructure communication networks and organizational structures. Secondly: the effective elements that are capable of learning and adapting to the changing environments that are able to use equipment and resources while sharing information with local managers and communities (Kamolvej ,2006).

Information systems that are used during crises have a positive impact on the response to crises due to the strategic role of information technology in absorbing the advanced information systems that support information during crises. This enables information systems to benefit and respond to crisis and strengthen the resources of systems in order to mitigate the crisis through capturing and storing the necessary information.

In addition, these systems have the ability to quickly transfer information into the system as well as the ability to exchange information in a timely manner since the documents and data are electronically stored and contribute in solving many issues and crises. (Neubauer, 2007).

Information systems work in the following way: (Increasing the integration of data, giving greater and better opportunity to analyze intelligence data in a timely manner, improving the quality of data in a timely manner, improve the investigative processes, maintain and make information available to investigators, improvements in the decision-making processes by making information available earlier.

In addition, the use of information systems saves time, effort and speed of performance during crises (Neubauer, 2007) This confirms that there is a strong relationship between information and communications systems as well as an enhanced level of crisis management effectiveness in addition to the impact of the effectiveness of information systems in the management of industrial companies during crises encountered. (Khashali and Qutub, 2006). The most important problems and obstacles that limit the efficiency of crises management are the lack of databases and information in the field of crisis and disaster management, the lack of suitable software, insufficient resources and devices, solutions to avoid obstacles of using information systems and lack of a good integrated systems (Verma \& Sehgal, 2016).

Information systems play an important role in decision making during crises, including the emphasis on the availability of infrastructure for the application of information systems, as well as information requirements for crisis management and the creation of good infrastructure that ensures the provision of information services in an appropriate manner (Ghareb, 2018). This then illustrates that there is an interest in information as it has an effective role in crisis management.

Accordingly, the success of information systems indicates to the positive impact of information systems in improving performance and reducing overall costs. In order to provide the information service to users at a high level of quality, especially in light of the rapid changes and crises that have occurred where users need information. Further, the change in the role of information systems has created required the organizations to provide high- 
quality information systems. Organizations have to make ensure that information systems are capable to provide services and information to the user as and when needed especially during crises(Ghareb, 2018).

Several models and approaches have been used to illustrate how the quality of information system is assessed. This includes the Delone McLean success model of Information system. This model identified the success factors of information systems in the work environment by illustrating the interrelationships between information system quality dimensions, standards and the tools used to measure the extent of achieving efficiency of the information system.

A model that was published in 1992, which was used to measure the success of information systems and was used in many studies where researchers noted that the quality and information systems are sufficient to accommodate the basic characteristics of information systems.

System Quality: This can be defined as the performance of IS (Petter and McLean, 2009) which includes software and data components that measure the system's technical capability.

To measure the quality of a system (Bailey and Pearson,1983), (Yang et al., 2005), and (Kim et al. , 2009), (Hamilton and Chervany,1981), (Bailey and Pearson, 1983), and (Srinivasan,1985), (Lee and Ok ,2004) (DeLone and McLean, 1992) proposed the most important factors that are desired and are expressed in the following: (Usability, Availability, Reliability, Adaptability, Response time).By comparing the system quality dimensions specified in ISO-9126 as well as the system quality in the IS-Impact model, the results showed that both groups have validity. On the other hand, (Ali \& et al,2012) study showed that both models had sufficient strength to be used in assessing system quality.

Information quality :Information quality is defined as the quality of the report or output that is produced and displayed by an IS (DeLone and MacLean, 1992), ( Gorla et al., 2010) (malek \&et al,2018) in the form of read reports or on electronic or audiovisual screens. Wang and Strong (1996) classified information quality into four dimensions: intrinsic, contextual, representational, and accessibility. The frequently and commonly mentioned measures and dimensions of information quality are: Completeness, understandability, accuracy, timeliness, Relevance and Security. (DeLone and McLean, 1992),(Wang and Strong, 1996), (Jarke and Vassiliou, 1997), (Herrera-Viedma et al., 2006).

As for the quality of the information, it appears in the information produced by the system and its usefulness to the user as it should be desired through the previous dimensions. The results of the (Alhendawi \& Baharudin, 2013)\& (malek \&et al,2018) study's showed that there is a strong correlation and relationship between the elements of quality of information systems and the performance of the employees in the organization. Any improvement in the quality of the information and services will positively affect the performance of the employees' tasks. The dimensions of the model for both the quality of the information and the quality of the systems will affect the employees' and the organization as well. (Amin, 2010). (Gorla, Somers, \& Wong, 2010), in a study that aimed at evaluating the success of the model of the information systems through the quality of both the system and information. The study found that the quality of the information is a major mediator between the quality of the system and the influence on the organization, with a strong relationship between the quality of information and the impact on the organization. The study of (Monem, Afrasiabi, Rezvan, \& Dehkordi, 2013) confirmed that the quality of the information has a strong impact on the quality of use and that the quality of the information and the quality of the user have an effect on the quality of using the system. The quality of the system is considered as one of the most important dimensions in measuring the success of the organization's ERP systems compared with the quality of information (Darko, Milan, Andra, Miodrag, Patrik, \& Izet, 2011), (malek \&et al,2018). The study of (Ndiege, Way, \& Herselman, 2012) identified the factors that are related to poor quality of the system, namely: the weak knowledge of information systems skills by both managers and users, weak participation of users in building information systems in the organization, the failure to identify the basic needs for the user of information systems in addition to the weakness of administrative decisions through which the applications and solutions of information systems within the organization are adapted. Consequently, information systems have an impact on improving the functioning of organizations and can greatly improve their performance. This impact and improvement takes place because the organization is studying the needs of users of information systems and works to develop the quality system that meets these needs. This is done by organizing hypotheses, concepts and designing principles to provide flexible and dynamic frameworks for the development of a quality information system so as to respond to emergencies and crises that will support and manage the administration as well as responding directly to them in case of crisis. There should be a kind of coordination among all concerned parties and agencies (Turoff, Chumer, Walle \& Yao, 2004). 


\section{Material and method}

This applied study attempted to identify the impact of system quality and information quality on crisis management in the Jordanian mobile telecommunication companies. This study begins with literature review and presents the previous studies in order to extract the most frequent factors that affect crisis management by various companies, conducting a survey on the managers of Jordanian mobile telecommunication companies ( 3 telecommunication companies: Zain, Orange and Umniah) that were used for this study. The sample included the entire study population; the questionnaires were distributed to 85 managers who occupy executive and intermediate levels in Jordanian mobile telecommunication companies and 80 questionnaires were returned.

The survey consisted of four parts. First: paragraphs that describe the characteristics of the sample. The second part contained paragraphs related to the quality of the system. The third part included paragraphs related to the information quality and the forth part included paragraphs related to crisis management.

This was followed by a 5-point Likert scale for the interpretation of participants' responses to the survey questions, multiple linear regressions. The statistical test was used to test the hypothesis of the research.

System quality and information quality factors served as (independent variables) and were examined against "Crisis Management" (a dependent variable).

\section{Results and Discussion}

\subsection{Demographic Information}

In order to describe the characteristics of the study sample: (gender, age, educational level and years of experience) (Table 1). It was found that the percentage of male $(68.7 \%)$ is approximately double the percentage of female participants $(31.3 \%)$. This indicates that females were a minority in the sample.

The analysis of age variable reflects that nearly two thirds $(62.5 \%)$ of the sample aged between (30 -50 years) indicating that this was the greatest age category followed by the participants aged ( $>50$ years $)(31.2 \%)$ and that the youth participants were the least aged $(<30)$ category $(6.3 \%)$.

Concerning the education level variable, it was clear that the Bachelor degree formed half of the sample (50.0\%). No participants hold less than a bachelors' degree $(0.0 \%)$ and the holders of masters' degree were greater $(37.5 \%)$ than the PhD (12.5\%). Inspecting the percentages of participants according to their experience, the results show that the participants who posses longer experience were the greatest $(43.7 \%)$ followed by the participants with moderate experience (10 -15 years) $(37.5 \%)$ and that participants with short experience were the less participants $(18.8 \%)$.

Table 1: characteristics of the sample

\begin{tabular}{|l|c|c|}
\hline \multicolumn{1}{|c|}{ Demographic variable } & Frequency & Percentage \\
\hline Gender & & \\
\hline Male & 55 & 68.7 \\
\hline Female & 25 & 31.3 \\
\hline Age & 5 & \\
\hline$<30$ & 50 & 6.3 \\
\hline $30-50$ & 25 & 31.2 \\
\hline$>50$ & & \\
\hline Academic qualifications & 0 & 0.0 \\
\hline Less than bachelor & 40 & 50.0 \\
\hline Bachelor & 30 & 37.5 \\
\hline Master & 10 & 12.5 \\
\hline Phd & & \\
\hline Experience & 15 & 18.8 \\
\hline$<10$ years & 30 & 37.5 \\
\hline $10-15 y e a r s$ & 35 & 43.7 \\
\hline More than 15 years & & \\
\hline
\end{tabular}




\subsection{System Quality :}

Table (2) presents the results of means, standard deviations and the relative importance of the items of System Quality: (Usability, Availability, Reliability, Adaptability, Response time).

Table (2): means and standard deviations for the items of system quality

\begin{tabular}{|c|c|c|c|c|c|}
\hline & items & Mean & SD & Rank & Importance \\
\hline 1 & $\begin{array}{l}\text { The current information system always provides me with } \\
\text { adequate information on system problems. }\end{array}$ & 3.89 & .87 & 12 & High \\
\hline 2 & The information system is easy to use. & 4.16 & 0.91 & 7 & High \\
\hline 3 & The information system always operates as it should. & 4.15 & .65 & 9 & High \\
\hline 4 & $\begin{array}{l}\text { The current information system helps me reach the best } \\
\text { solutions. }\end{array}$ & 4.03 & .68 & 10 & High \\
\hline 5 & $\begin{array}{l}\text { The information system requires a few screens and files to } \\
\text { accomplish the task. }\end{array}$ & 4.28 & .78 & 4 & High \\
\hline 6 & $\begin{array}{l}\text { The information system can be easily modified, repaired and } \\
\text { improved. }\end{array}$ & 3.98 & 92 & 11 & High \\
\hline 7 & The current information system responds quickly. & 4.26 & .77 & 5 & High \\
\hline 8 & $\begin{array}{l}\text { The current information system analyzes, simplifies and } \\
\text { facilitates understanding of complex problems. }\end{array}$ & 4.35 & 0.58 & 2 & High \\
\hline 9 & $\begin{array}{l}\text { The current system provides computerized programs that are } \\
\text { compatible with the requirements of the work of each } \\
\text { administrative level. }\end{array}$ & 4.22 & 0.93 & 6 & High \\
\hline 10 & $\begin{array}{l}\text { The current information system provides safe and accurate } \\
\text { information. }\end{array}$ & 4.46 & 0.68 & 3 & High \\
\hline 11 & $\begin{array}{l}\text { The current information system contains features that protect } \\
\text { information and reduces errors. }\end{array}$ & 4.12 & 0.68 & 8 & High \\
\hline \multirow[t]{2}{*}{12} & $\begin{array}{l}\text { The current information system allows all administrative levels } \\
\text { the ability to plan and organize their work. }\end{array}$ & 4.60 & 0.61 & 1 & High \\
\hline & System Quality & 4.20 & .75 & & High \\
\hline
\end{tabular}

Mean ranks (2.33 and less: low; 2.34 - 3.67: moderate; 3.68 and more: high)

Table (2) shows the values of means and standard deviations for the items of System Quality. The mean values ranged between (3.89- 4.60). Item No. (12), states: "The current information system enables all administrative levels the to plan and organize their work." Had a recorded the highest mean (4.60) and ranked first while item No. (1) state that: "The current information system provides me with sufficient information on the problem, had had recorded the least mean (3.89) and ranked the last. The overall System Quality was evaluated in a high degree with a mean of (4.20). This emphasized the importance of flexibility in the relationships between the parts of the system and the entire system and its comprehensiveness to serve crisis management effectively as well as the importance of interactive exchange between crisis management systems and the environment surrounding the system within and outside the organization.

\section{3 information Quality :}

Table (3) shows the arithmetical averages, standard deviations and the relative importance of all paragraphs related to information quality (Completeness, understandability, accuracy, timeliness, Relevance, Security). 
Table (3): means and standard deviations for the items of information quality

\begin{tabular}{|r|l|c|c|c|c|}
\hline \multicolumn{1}{|c|}{ Paragraphs } & Mean & SD & Rank & Importance \\
\hline 1 & $\begin{array}{l}\text { I can use the information I get from the information system in my } \\
\text { work. }\end{array}$ & 3.89 & .87 & 10 & High \\
\hline 2 & The information I get from the information system is understandable. & 4.15 & .65 & 6 & High \\
\hline 3 & Errors in the information system are within acceptable limits. & 4.03 & .68 & 7 & High \\
\hline 4 & $\begin{array}{l}\text { Information in the information system is clearly readable and } \\
\text { formatted }\end{array}$ & 4.18 & 0.72 & 4 & High \\
\hline 5 & $\begin{array}{l}\text { The information that I need from the information system is always } \\
\text { available. }\end{array}$ & 4.12 & 0.68 & 8 & High \\
\hline 6 & $\begin{array}{l}\text { Information provided by the system is comprehensive for all possible } \\
\text { alternative solutions. }\end{array}$ & 4.34 & 0.77 & 1 & High \\
\hline 7 & $\begin{array}{l}\text { The current information system helps to produce clear, easily } \\
\text { understood reports. }\end{array}$ & 4.16 & 0.91 & 5 & High \\
\hline 8 & $\begin{array}{l}\text { Data in the information system is integrated and consistent. } \\
\text { The information I receive is constantly updated. }\end{array}$ & 4.20 & 0.70 & 3 & High \\
\hline 10 & $\begin{array}{l}\text { The powers of access to information are given according to the } \\
\text { administrative level. }\end{array}$ & 3.98 & .78 & 2 & High \\
\hline & Information Quality & 4.13 & .76 & 9 & High \\
\hline
\end{tabular}

Mean ranks (2.33 and less: low; 2.34 - 3.67: moderate; 3.68 and more: high)

Table (3) declares the mean values and standard deviations of the items of information quality. the means values ranged between $(3.89$ - 4.34). it was clear that item No. (6) which states "Information provided by the system is comprehensive for all possible alternative solutions." had had ranked the first by a mean (4.34).

While item No. (1) which states: "I can use the information I get from the information system in my work," had ranked the last by a mean of (3.89). the overall degree of information quality was evaluated by a mean of (4.13). This underscores the crucial role of information in increasing the effectiveness of crisis management in terms of organization and response to chaotic and random behavior within the organization.

\subsection{Crisis Management:}

Table (4) reflects the means values and standard deviations and the relative importance of items of crisis management

Table (4): means and standard deviations for the items of crises management.

\begin{tabular}{|c|c|c|c|c|c|}
\hline & Paragraphs & Mean & SD & Rank & Importance \\
\hline 1 & $\begin{array}{l}\text { Provides adequate and ready crisis management programs and } \\
\text { plans. }\end{array}$ & 4.16 & 0.91 & 4 & High \\
\hline 2 & $\begin{array}{l}\text { A comprehensive survey of the environment is conducted in order } \\
\text { to identify signs of potential crises. }\end{array}$ & 4.15 & .65 & 5 & High \\
\hline 3 & The department reviews and evaluates all related procedures. & 4.03 & .68 & 8 & High \\
\hline 4 & $\begin{array}{l}\text { Programs and plans related to crisis management are continuously } \\
\text { developed and reviewed. }\end{array}$ & 4.28 & .78 & 2 & High \\
\hline 5 & $\begin{array}{l}\text { Crises are controlled when it occurs within an appropriate period } \\
\text { of time. }\end{array}$ & 3.98 & .92 & 9 & High \\
\hline 6 & $\begin{array}{l}\text { The system prevents sub-crises that may result from the main } \\
\text { crisis. }\end{array}$ & 3.92 & 0.90 & 10 & High \\
\hline 7 & $\begin{array}{l}\text { The Department identifies the needs for the different sites affected } \\
\text { by the crisis. }\end{array}$ & 4.11 & 0.69 & 6 & High \\
\hline 8 & Management learns from past crises. & 3.91 & 0.81 & 11 & High \\
\hline 9 & Lessons are learned from previous crises. & 4.34 & 0.63 & 1 & High \\
\hline 10 & $\begin{array}{l}\text { The Department benefits from crisis management techniques in } \\
\text { other institutions that had similar experiences whether local, } \\
\text { regional or international. }\end{array}$ & 4.17 & 0.61 & 3 & High \\
\hline 11 & Early detection signals for crises are available. & 3.89 & .87 & 12 & High \\
\hline \multirow[t]{2}{*}{12} & $\begin{array}{l}\text { Future crisis management plans are developed using past } \\
\text { experiences. }\end{array}$ & 4.04 & 0.73 & 7 & High \\
\hline & The Crisis Management. & 4.08 & .76 & & High \\
\hline
\end{tabular}

Mean ranks (2.33 and less: low; 2.34 - 3.67: moderate; 3.68 and more: high)

Table (4) presents the means of values and standard deviations of the items of crises management. Inspecting the means column, it was clear that the mean values range between (3.89- 4.34). Item No. (9) stated" lessons were learned from previous experience" had ranked the first by a mean of (4.34). Item No. (11) stated: "Early detection 
signals for crises are available" occupied the last rank by a mean of (3.89). This emphasizes the importance of learning and benefit from past lessons in addition to the need for disseminating what was learned through information systems to avoid the same crises in the future. There should be more focus on developing early detection systems to manage the crises.

\subsection{Testing the Hypothesis \\ 4.5.1 The main hypothesis:}

H0: There is No. statistically significant effect at the level $(\alpha \leq 0.05)$ for (system quality and information quality) on crisis management in the Jordanian mobile telecommunication companies.

This hypothesis was tested by using multiple linear regressions and the results were as follows:

Table (5): multiple linear regression results for the effect of (system quality and information quality) on crisis management

\begin{tabular}{|c|c|c|c|c|c|c|c|c|}
\hline \multicolumn{4}{|c|}{ Model indicators } & \multicolumn{5}{|c|}{ Coefficients } \\
\hline $\mathbf{R}$ & $\mathbf{R}^{2}$ & f & F sig & Predictors (independents) & $\beta$ & $\mathbf{t}$ & Sig. $t$ & VIF \\
\hline \multirow{2}{*}{.924} & \multirow{2}{*}{.853} & \multirow{2}{*}{620.19} & \multirow{2}{*}{0.000} & system Quality & 0.428 & 17.32 & 0.000 & 1.29 \\
\hline & & & & information Quality & 0.346 & 18.61 & 0.000 & 1.29 \\
\hline
\end{tabular}

Table (5) shows the results of multiple linear regression for the effect of (system quality and information quality) on crisis management. The f value (620.19), this value was significant because the related probability value $(0.000)$ was statistically significant $(<0.05)$. the last column in the table indicates the values of (VIF) as an indicator test for multi co linearity. the value (1.29) is considered to reflect no problem of multi co linearity as this value was $(<10)$. The value of $\mathrm{R} 2$ expresses the variation percentage in the dependent variable that can be accounted for (i.e. explained by) the independent variable was $(85.3 \%)$. The beta coefficients reflect the impact value of each predictor variable (independent variable). The results show that the quality of systems affects the crisis management (0.428) larger than the information quality which was found to affect the crisis management by a value of (0.346). The ( $\mathrm{t}$ ) statistics tests the linearity importance of the beta coefficient was obtained for the independent variable. Inspecting the results of probabilities of $(\mathrm{t})$ statistic revealed that the observed probabilities were $(0.000)$ and $(0.000)$ respectively. Based on the probability of $(f)$ test which was $(0.000)$ the null hypothesis is rejected and the alternative one is accepted.These results are consistent with the results of (Ghareb, 2018),(Verma, Sehgal, 2016), (kamolvej,2006), (Khashali, Qutub, 2007), (Neubauer, 2007), (Turoff, Chumer,de Walle, and Yao, 2004),(Amin, 2010), (Alhendawi \& Baharudin ,2013) (Ghareb, 2018) (malek \&et al,2018) studies. The results confirm that there is a strong correlation between the (system quality, information quality) in crisis management and the performance of employees in the organization and pointed out that the dimensions of the model for both qualities of information and quality of systems have an impact on individuals, the organization and management crisis it counters.

\subsubsection{The first sub-hypothesis:}

H01: There is no statistical significant effect at the level of $(\alpha<0.05)$ for the system quality in crisis management in the Jordanian mobile telecommunication companies.

The results of testing the hypothesis are presented in the following table:

Table (6): Simple regression of the effect of system quality on crisis management.

\begin{tabular}{|c|c|c|c|c|c|c|c|}
\hline Independent & $\mathbf{R}$ & $\mathbf{R}^{2}$ & $\mathbf{F}$ & Sig f & $\boldsymbol{\beta}$ & $\mathbf{t}$ & Sig t \\
\hline System quality & 0.804 & 0.647 & 393.22 & 0.000 & 0.804 & 19.83 & 0.000 \\
\hline
\end{tabular}

Table (6) shows that the quality of systems affects the crisis management in Jordanian mobile telecommunication companies. The correlation coefficient $(\mathrm{R})$ was (.804) which indicates to a positive relationship for the system quality as a predictor of crisis management in Jordanian mobile telecommunication companies.

The $\mathrm{R}^{2}$ (determination coefficient) expresses the amount of variation in the dependent variable values that may be assigned (referred to or explained) to the independent variable; this value was $(64.7 \%)$. 
Concerning the effect (impact) value it was expresses by the $\beta$ coefficient which was $(0.804)$ this impact value is considered to be statistically significant as the related probability of $t(0.000)$ was $(<0.05)$ reflecting a linear contribution and importance to the dependent variable.

Based on the probability value of $f$ test which was $(0.000)$; clearly this value was $(<0.05)$ suggesting significant effect for system quality on crises management; the null hypothesis is rejected concluding significant effect of the independent variable on the dependent variable. These results are consistent with the results of (Ghareb, 2018), (Verma, Sehgal,2016), (Darko, Milan, Andra, Miodrag, Patrik, \& Izet, 2011). (Gorla, Somers \& Wong, 2010). (Ndiege, Way, \& Herselman, 2012). (Ali, Raba'ii, Tate, \& Zhang, 2012) (malek \&et al,2018) studies. They pointed to the importance of the system quality in the performance of the organizations and crisis management and the improvement of its operations.

\subsubsection{The second sub-hypothesis:}

H02: There is no statistical significant effect at the level of $(\alpha<0.05)$ for the information quality on crisis management in Jordanian mobile telecommunication companies.

The results are shown in the table (7).

Table (7): Simple regression for the effect of information quality on crisis management.

\begin{tabular}{|c|l|l|l|l|l|l|r|}
\hline independent & $\mathbf{R}$ & $\mathbf{R}^{\mathbf{2}}$ & $\mathbf{F}$ & Sig f & $\boldsymbol{\beta}$ & \multicolumn{1}{|c|}{ t } & Sig t \\
\hline information quality & 0.784 & 0.614 & 342.71 & 0.000 & 0.784 & 18.51 & 0.000 \\
\hline
\end{tabular}

Table (7) shows that the quality of information affects the crisis management in Jordanian mobile telecommunication companies. The correlation coefficient $(\mathrm{R})$ was found to be (.784) suggesting a positive relationship for the information quality as a predictor of crisis management in Jordanian mobile telecommunication companies. The $\mathrm{R}^{2}$ (coefficient of determination) expresses the amount of variation in the dependent variable values that may be assigned (referred to or explained) to the independent variable; this value was (61.4 \%).

Concerning the effect value (impact) which represented by the $\beta$ coefficient; it was found to be (0.784); this impact value is considered to be statistically significant as the related probability of $t(0.000)$ was $(<0.05)$ reflecting a linear contribution and importance to the dependent variable.

Based on the probability value of $f$ test which was $(0.000)$; clearly this value was $(<0.05)$ suggesting significant effect for information quality on crises management; the null hypothesis is rejected concluding significant effect of the independent variable on the dependent variable. This result is consistent with the results of the (Ghareb, 2018), (Verma, Sehgal, 2016) (kamolvej, 2006), (Monem, Afrasiabi, Rezvan, \& Dehkordi, 2013), (Dörr,Walther \& Eymann, 2013) (malek \& et al,2018) studies, which indicated that the quality of information has a strong impact on the quality of usage and on the performance of workers and in dealing and managing the crisis.

(Gorla, Somers, \& Wong, 2010) strongly emphasized that the quality of information is a key factor that has a great impact on performance in addition to the existence of a strong relationship between the quality of information and the impact on the organization and Success in confronting and responding to crises.

\section{Conclusion and Recommendations \\ 5.1 Conclusion}

The average of the total relative weights of the quality elements of the (system quality \& information quality) found that the Jordanian mobile telecommunication companies have high-quality information systems that are suitable to the administrative levels and enjoy good information protection. All elements related to system quality contribute to the quality of information systems in very close and small increments. The most influential element of the current information systems allows the employees at different administrative levels to be able to plan and organize their work. As a result, the system should be suitable to serve all administrative levels without overlapping authority. It is important that the current information system components provide safe and accurate information. This result underscores the importance of information security at work and hence the rest of the components in close proportion. All elements related to the information quality contribute to the quality of information systems in very close and small increments. The most influential element of the information provided by the system is comprehensive information about all alternatives to possible solutions. Therefore, the system should provide comprehensive information for all possible solutions to assist decision-makers. The importance of the information that is received should be constantly updated. It is necessary for the system to provide updated information continuously without interruption to provide all new developments to the decision-maker. This result confirms the 
importance of the universality and timeliness of the information provided by the system. The rest of the elements follow in close approximations. All elements related to crisis management contribute to the management of crises effectively and successfully at close increments with small differences. The most influential element is the lessons learned from previous crises, because of the need and importance of learning from previous lessons plus the dissemination of what was learned. It is critically important that the programs and plans for crisis management are continuously developed and reviewed. The need to update the plans and programs continuously emphasizes the importance of comprehensiveness and modernity of plans and programs as well as the use of information systems to provide all the latest information to update the plans. The rest of the elements are relatively comparable. There is a strong statistical significance between (system quality \& information quality) and the ability of Jordanian mobile telecommunication companies to manage the crises. The study concluded that ( $85.3 \%)$ of the variation in crisis management are explained by both (system quality \& information quality).

This is an excellent percentage which illustrates the importance of (system quality \& information quality) and their impact on crisis management. However, there is a strong statistical significance between the system quality and the ability of Jordanian mobile telecommunication companies to manage crises. The study concluded that (64.7\%) of the variation in crisis management are explained by system quality. This demonstrates the importance of system quality and its impact on crisis management. There is a strong statistical significance between the information quality and the ability of Jordanian mobile telecommunication companies to manage crises. The study concluded that $(61.4 \%)$ of the variation in crisis management are explained by information quality. This demonstrates the importance of information quality and its impact on crisis management.

\subsection{Recommendations:}

In light of the study, the researcher would propose a set of recommendations, namely:

- Increase interest in information systems because they are the keystone of the operations and the quality of the information systems that enable organizations to avoid crises and mitigate the negative effects in the event they occur.

- $\quad$ Provide more attention for studying the different factors of quality measurement in information systems and their impact on crisis management.

- Well- informed companies should not only transfer information technology, but they should also strive to achieve the best performance by setting standards to obtain the quality of information that contributes to the correct decisions during crises.

- Provide more concentration and attention to create and establish special units to collect, analyze and store crisis information on databases in information systems that would also provide pre-packaged solutions to meet expected crises.

- Coordinate and integrate systems between governmental and non -governmental sectors and other relevant sectors in order to benefit from ensuring the flow of information from the locations of events, analyzing, evaluating and submitting them to the decision-makers.

\section{References :}

Alhendawi, K., \& Baharudin, A. S. (2013). The Impact of Quality Factors of Web-based Information System on The Employee Task Performance: A Pilot Study. Journal of Theoretical and Applied Information Technology, $52(3)$.

Ali, A., Raba'ii, A., Tate, M., \& Zhang, M. (2012). A Critical Evaluation and Comparison of Two Formative Measures of System Quality Using Criterion Variables. In L. John (Ed.), Australasian Conference on Information Systems (23rd: 2012: Geelong, Victoria) (pp. 1-10.). [Geelong, Vic.]: ACIS.

Amin, M. A. (2010). Measuring The Performance Of Customs Information Systems (CIS) in Malaysia. World Customs Journal, 4(2).

Bailey, J.E. and Pearson, S.W., (1983) Development of a tool for measuring and analyzing computer user satisfaction, Management Science, Vol. 29, No. 5, pp. 530-545.

Darko, S., Milan, M., Andra, A., Miodrag, D., Patrik, D., \& Izet, R. (2011). Investigating ERP Systems Success From The End User Perspective. TTEM- Technics Technologies Education Management, 6(4), 1089. 
DeLone, W.H. and McLean, E.R., (1992) Information Systems Success: The Quest for the Dependent Variable, Information Systems Research, Vol. 3, No. 1, pp. 60-95.

Dörr, S., Walther, S., \& Eymann, T. (2013). Information Systems Success - A Quantitative Literature Review and Comparison. International Conference on Wirtschaftsinformatik, Leipzig.

Ghareb, Mazen. (2018), Information Technology Roles in Crisis Management: A Case Study in Kurdistan Region Government, International Journal of Computer Engineering and Information Technology, VOL. 10, No, 5, PP: 71-78.

Gorla, N., Somers, T., \& Wong, B. (2010). Organizational Impact Of System Quality, Information Quality, And Service Quality. Journal Of Strategic Information Systems. 19, 207-228

Hamilton, S. and Chervany, N.L.(1981), Evaluating information system effectiveness-Part I: Comparing evaluation approaches, MIS Quarterly, Vol. 5, No. 3, pp. 55-69.

Herrera-Viedma, E., Pasi, G., Lopez-Herrera, A.G., and Carlos, P., (2006)"Evaluating the information quality of Web sites: A methodology based on fuzzy computing with words," Journal of the American Society for Information Science and Technology, Vol. 57, No. 4, pp. 538-549.

Jaouad ,E .,\& Lahsen, O.(2018) Factors Affecting Bank Performance: Empirical Evidence from Morocco .European Scientific Journal, ESJ, 14,34. Doi:10.19044/esj.2018.v14n34p255.

Jarke, M. and Vassiliou Y., (1997) Data Warehouse Quality: a review of the DWQ project, Proceedings of the Conference on Information Quality, Cambridge, MA: Citeseer, pp. 299-313.

kamolvej , tavida,(2006), the integration of intergovernmental coordination and information management in response to immediate crises Thailand emergency management, Ph.D. dissertation, university of Pittsburgh.

Kim, C., Oh, E., Shin, N., and Chae, M.,(2009) An empirical investigation of factors affecting ubiquitous computing use and Business value, International Journal of Information Management, Vol. 29, No. 6, pp. 436448.

Khashali, Shaker Jarallah, Qutub, Muhyiddin (2007), The effectiveness of management information systems and their impact on crisis management: An empirical Study in Jordanian industrial companies, Jordanian Journal of Administration, 3(1). 22-44.

Lee, B.H. and Ok, S.J., (2004) A Study of the Success Factors on the Mobile Office System," Internet eCommerce Research, Vol. 4, No. 2, pp. 33-47.

Malik, B. H., Shuqin, C., Qamar, S., \& Mattiullah, B. (2016). Examining Success of Land Record Information Systems (LRMIS) in Pakistan: Validating an Incorporated IS Success Model. European Scientific Journal, 12(2). doi: 10.19044/esj.2016.v12n2p258

Monem, H., Afrasiabi, M., Rezvan, P., \& Dehkordi, S. A. (2013). The Impact of User Quality And Information Quality on The IS Success In Healthcare Context. Journal Of Basic And Applied Scientific Research, 3(10), 4051.

Ndiege, J. R., Way, N., \& Herselman, M. (2012). Quality Assessment Of Information Systems In SMEs. 2(51),123

Neubauer, J Michael. (2007).A Systems Analysis of Information Technology and the Use of WLANs Implemented by an FBI Field Office for Crisis Response Incidents :The Columbia Field Office Case Study, Ph.D. dissertation, Nova Southeastern University.

Pearson, Christine M and Mittroff, Ian I,(1993) from crisis-prone to crisis prepared: a framework for crisis management, Academy of Management Executive, 7( 1), 155-164.

Petter, S. and McLean, E.R.,(2009) A meta-analytic assessment of the DeLone and McLean IS success model: An examination of IS success at the individual level, Information and Management, Vol. 46, No. 3, pp. 159-166.

Srinivasan, A.,(1985) Alternative measures of system effectiveness: associations and implications, MIS Quarterly, Vol. 9, No. 3, pp. 243-253.

Turoff, Murray; Chumer, Michael; de Walle, Bartel Van; and Yao, Xiang. (2004). The Design of a Dynamic Emergency Response Management Information System (DERMIS), Journal of Information Technology Theory and Application (JITTA),5(4). 
Verma, R., \& Sehgal, V. K. (2016). Implementation of Information System in Crisis Management Using Modeling and Simulation. International Journal of Simulation--Systems, Science \& Technology, 17(32).

Wang, R.Y. and Strong, D.M.,(1996) Beyond accuracy: What data quality means to data consumers, Journal of Management Information Systems, Vol. 12, No. 4, pp. 5-33.

Yang, Z., Cai, S., Zhou, Z., and Zhou, N., (2005) Development and validation of an instrument to measure user perceived service quality of information presenting web portals, Information and Management, Vol.42, No. 4, pp. 575-589.

Zaied, A. H. (2012). An E-Services Success Measurement Framework. International Journal of Information Technology And Computer Science(IJITCS),4(4),18-25. 